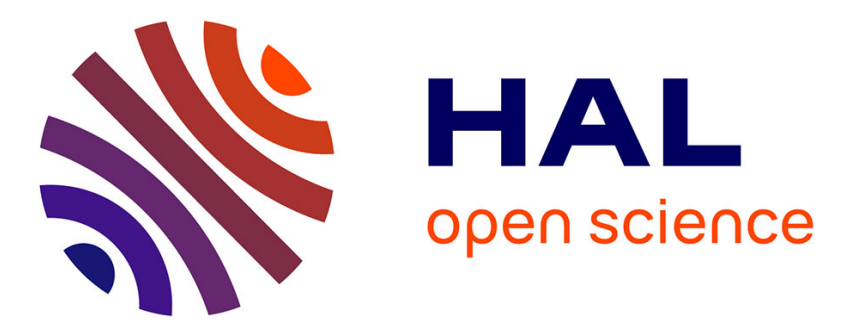

\title{
Are European starlings breeding in the Azores archipelago genetically distinct from birds breeding in mainland Europe?
}

Verónica C. Neves, Kate Griffiths, Fiona R. Savory, Robert W. Furness, Barbara K. Mable

\section{To cite this version:}

Verónica C. Neves, Kate Griffiths, Fiona R. Savory, Robert W. Furness, Barbara K. Mable. Are European starlings breeding in the Azores archipelago genetically distinct from birds breeding in mainland Europe?. European Journal of Wildlife Research, 2009, 56 (1), pp.95-100. 10.1007/s10344009-0316-x . hal-00535248

\section{HAL Id: hal-00535248 \\ https://hal.science/hal-00535248}

Submitted on 11 Nov 2010

HAL is a multi-disciplinary open access archive for the deposit and dissemination of scientific research documents, whether they are published or not. The documents may come from teaching and research institutions in France or abroad, or from public or private research centers.
L'archive ouverte pluridisciplinaire HAL, est destinée au dépôt et à la diffusion de documents scientifiques de niveau recherche, publiés ou non, émanant des établissements d'enseignement et de recherche français ou étrangers, des laboratoires publics ou privés. 


\title{
Are European starlings breeding in the Azores archipelago genetically distinct from birds breeding in mainland Europe?
}

\author{
Verónica C. Neves • Kate Griffiths • Fiona R. Savory • \\ Robert W. Furness • Barbara K. Mable
}

Received: 6 May 2009/Revised: 5 August 2009 / Accepted: 11 August 2009/Published online: 29 August 2009

(C) Springer-Verlag 2009

\begin{abstract}
The European starling (Sturnus vulgaris) has recently been found to eat eggs of the endangered roseate tern (Sterna dougallii) in the Azores. Azorean starlings are considered an endemic subspecies ( $S$. vulgaris granti), so we investigated how much genetic divergence has accumulated between the Azores and other European populations in order to assess whether lethal control measures might be possible, as previous experiments have found that taste aversion is not likely to be successful. For this purpose, we sequenced a region of the protein-coding mitochondrial gene ND2 for samples from six different populations. Of the 1,026 base pairs sequenced, 19 (1.7\%) were variable and formed 15 different haplotypes. The Azores had high and significant genetic differentiation from all the other populations studied. Haplotype diversity was high in the mainland populations studied, ranging from 0.767 to 0.900 , but there was no variation among the Azores samples, which were collected from a geographically broad region. Given the lack of genetic variability in the Azores birds and their abundance throughout the archipelago, lethal control on a local basis and as part of an integrated control plan can be seen as a reasonable measure to protect tern colonies.
\end{abstract}

Communicated by W. Lutz

V. C. Neves · K. Griffiths • F. R. Savory • R. W. Furness •

B. K. Mable

Faculty of Biomedical and Life Sciences, Graham Kerr Building, University of Glasgow,

G12 8QQ Glasgow, UK

V. C. Neves $(\bowtie)$

IMAR-Açores,

Cais de Santa Cruz,

9901-862 Horta, Portugal

e-mail: neves_veronica@yahoo.com
Keywords Azores · Genetic divergence · ND2 · European starling $\cdot$ Conservation

\section{Introduction}

The nine islands that comprise the Azores are located in the Mid-North Atlantic around 1,500 km west of Portugal. European starlings (Sturnus vulgaris) breed on all of the islands; no estimate of population size is available, but they are particularly abundant on the islands of Santa Maria and Corvo (Equipa Atlas 2008). The Azorean starlings have been described as a subspecies, S. vulgaris granti (Hartert and Ogilvie-Grant 1905), but Vaurie (1959) questioned this separation since there is considerable overlap in biometrics and plumage with the nominate $S$. vulgaris vulgaris. The presence of the European starling in the Azores constitutes an intriguing geographic occurrence, as it does not breed in mainland Portugal or in the Atlantic archipelago of Madeira and has only recently (1960) become a regular breeder in Spain (Ferrer et al. 1991). Feare (1984) believes that the Azores starling may be a remnant of a former wide distribution of starlings that subsequently contracted to the north and east. Some bird species have been introduced to the Azores by man, e.g., the goldfinch (Carduelis carduelis) and more recently, the common sparrow (Passer domesticus; Bannerman and Bannerman 1966). However, according to historic documents, the European starling was already breeding in the Azores upon man's arrival and colonization of the islands (Frutuoso 1561). The Azores population is a year-round resident as opposed to the mainland Europe populations, which generally migrate southward in the winter.

In 2001, starlings were found to eat eggs of the common tern Sterna hirundo and the endangered roseate tern Sterna 
dougallii at Vila islet, off Santa Maria (predation rates were $73.1 \%$ and $90.2 \%$ in 2002 and 2003, respectively; Neves 2005). During 2007 and 2008, starlings were found to eat eggs at another tern colony, Praia islet located off Graciosa (V Neves, personal observation). A recent control taste aversion experiment did not prove to be effective in minimizing its impacts (Neves et al. 2006), and it is important to clarify the taxonomic status of the Azores starling before other measures to protect the terns are planned and undertaken.

Mitochondrial DNA (mtDNA) has proved very useful as a starting point to resolve phylogenetic relationships (Moritz et al. 1987) and NADH dehydrogenase II (ND2, $1,047 \mathrm{bp}$ ) is amongst the mtDNA genes that have proved most phylogenetically informative in studies on vertebrates (Johnson and Clayton 2000). Our objective was to investigate if the Azores population was genetically different from the mainland and other island populations and to assess genetic diversity within and among populations residing in the Azores. For this, we sequenced and compared the ND2 gene of six European populations: Azores, Spain, Fair Isle, Bristol, Glasgow, and Norway, along with published sequences from the USA and Sweden.

\section{Methods}

\section{DNA sampling}

We sampled blood from 33 live individuals in the wild from six populations of three subspecies: Azores (seven individuals, five from Terceira island and two from Santa Maria island)-S. vulgaris granti, Spain (five individuals) - S. vulgaris vulgaris, the UK (Bristol (five individuals) - S. vulgaris vulgaris, Glasgow (four individuals) - S. vulgaris vulgaris, and Fair Isle (six individuals) -S. vulgaris zetlandicus), and Norway (four individuals) - S. vulgaris vulgaris. Birds were caught by standard techniques, and $25 \mu \mathrm{l}$ of blood was taken using a conventional syringe and heparinized capillary tubesbirds were released immediately afterwards. Additionally, we obtained three other ND2 sequences from GenBank: two from European starlings collected in the USA (Michigan and New York, accession numbers AF407048 and EF468186, respectively; Sorenson and Payne 2001, Lovette and Rubenstein 2007) and one from a European starling collected in Sweden (accession number DQ146346; Fuchs et al. 2006). We also obtained ND2 sequences for two spotless starlings collected in Spain (accession numbers EF468185 and DQ466884; Lovette and Rubenstein 2007; Zuccon et al. 2006) to be used as an out-group in the phylogenetic analysis.
Preliminary polymerase chain reactions and mtDNA gene choice

We conducted trial polymerase chain reactions (PCRs) and sequenced two mitochondrial protein-coding genes, cyt $b$ and ND2, in two blood samples of European starling. The mitochondrial cytochrome-b (cyt $b$ ) gene has been more widely used to study species-level phylogenies in bird groups than has ND2 (Moore and DeFilippis 1997), and its rate of sequence divergence has also been well characterized (Fleischer et al. 1998). However, in this study, it was found that ND2 was more variable than cyt $b$. Despite the more generalized use of cyt $b, \mathrm{ND} 2$ is in fact one of the most variable genes (in terms of amino acid sequence) after ATPase 8 and ND6, which are relatively small and thus, provide less information than ND2 (Sorenson et al. 1999). To sequence the ND2 gene, we used primers H6313 (5' CTCTTATTTAAGGCTTTGAAGGC-3') and L5216 (5' GCCCATACCCCRAMAATG-3'; Sorenson et al. 1999). The letters $\mathrm{L}$ and $\mathrm{H}$ refer, respectively, to the light and heavy strands, and the numbers refer to the base position at the $3^{\prime}$ end of the primer in the complete chicken mtDNA sequence (Desjardins and Morais 1990).

DNA extraction, PCR amplification, and sequencing

Total genomic DNA was extracted from alcohol-preserved (Azores, Spain, and Norway) and TES buffer-preserved (Fair Isle, Bristol, and Glasgow) blood samples using proteinase $\mathrm{K}$ digestion, according to the manufacturer's protocol (DNeasy ${ }^{\circledR}$ blood and tissue kit by Qiagen). PCRs were performed in a $25-\mu \mathrm{l}$ reaction containing $1 \mu \mathrm{l}$ of template (10-50 ng of genomic DNA). The final reaction conditions were: $12.5 \mathrm{pmol}$ of each primer, $200 \mu \mathrm{M}$ of each dNTP, $1.5 \mathrm{mM} \mathrm{MgCl}_{2}, 50 \mathrm{mM} \mathrm{KCl}, 10 \mathrm{mM}$ TrisHCl, $0.1 \%$ TritonX-100, and 0.6 units of Taq polymerase. Amplifications were carried out for 30 cycles under the following profile: an initial denaturing temperature of $94^{\circ} \mathrm{C}$ for $120 \mathrm{~s}$, followed by an annealing temperature of $50^{\circ} \mathrm{C}$ for $60 \mathrm{~s}$, extension at $72^{\circ} \mathrm{C}$ for $60 \mathrm{~s}$, and denaturing temperature of $94^{\circ} \mathrm{C}$ for $45 \mathrm{~s}$, and final annealing and extension steps of $50^{\circ} \mathrm{C}$ for $60 \mathrm{~s}$ and $72^{\circ} \mathrm{C}$ for $5 \mathrm{~min}$, respectively. PCR products were purified by excising bands from $2 \%$ agarose gels with QIAquick Gel Extraction Kits, using the manufacturer's instructions (Qiagen) and then sequenced by an ABI 3730 automated sequencer at the University of Dundee.

mtDNA sequence analysis

Chromatographs were visualized, aligned, and corrected using Sequencher, version 4.1 (Gene Codes Corporation, Ann Arbor, MI, USA). MacClade version 4.0 was used 
Fig. 1 Haplotype network reconstructed using TCS 2.1 (Posada et al. 2000). The following acronyms were used for population locations: AZST Azores starlings; GLA Glasgow, Scotland; BRIS Bristol, England; FAIR Fair Isles, Scotland; SPAIN Catalonia, Spain; NOR Norway; $M I C H$ Michigan, USA; $N Y$ New York, USA; SWE Sweden. Haplotypes letter codes as in Table 1. Azores haplotype marked in a dashed line and spotted starling haplotypes marked in double line. Based on this reconstruction, the haplotype B shared by individuals from the Fair Isles, Norway, and Spain is hypothesized to be ancestral. The Azores population shows one fixed difference from this ancestral type

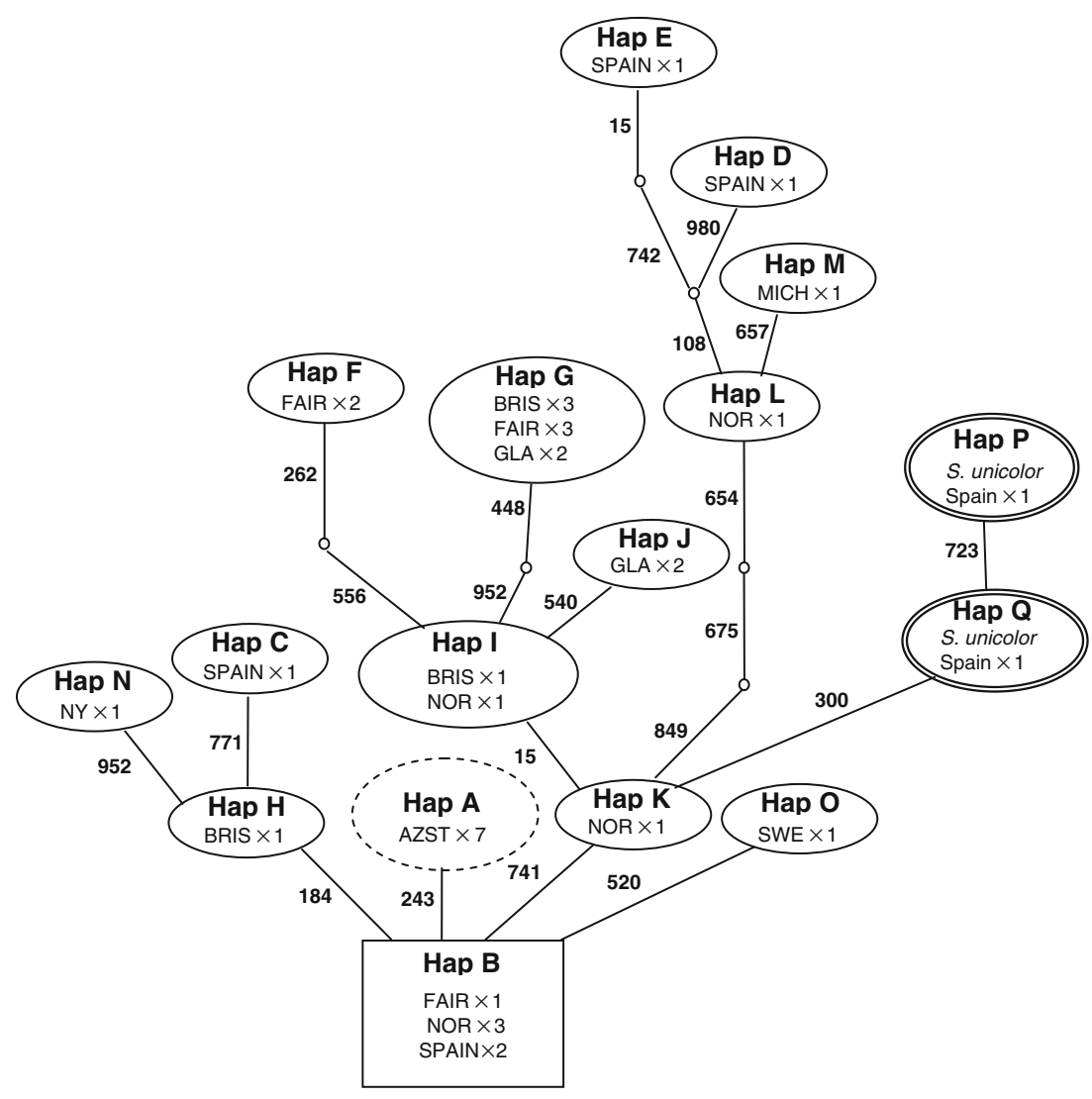

(Sinauer Assoc., MA, USA; Maddison and Maddison 2000) to visualize differences between sequences. Haplotype diversity was calculated using equation 8.5 of Nei (1987). Genetic differentiation was studied by calculating the pairwise $F_{\text {st }}$ values between the different populations studied, based on haplotype frequencies using Arlequin (version 3.1; Excoffier et al. 2006). To calculate the percentage of variation among and within populations and to assess the geographic pattern of population structure, we conducted an analysis of molecular variance using Arlequin. The program TCS (version 1.18) was used to construct a haplotype network and estimate gene genealogies (Clement et al. 2000). GenBank sequences from previous studies were only used in the haplotype network.

\section{Results}

We obtained mtDNA sequences for 33 European starlings. Nineteen (1.9\%) out of the 1,026 pair bases sequenced were variable, and there were 12 different haplotypes in our sample (GenBank accession numbers FJ896144 to

Table 1 Haplotype distribution and diversity among six European starling populations

\begin{tabular}{|c|c|c|c|c|c|c|c|c|c|c|c|c|c|c|c|}
\hline & \multicolumn{12}{|c|}{ Haplotype distribution } & \multicolumn{2}{|l|}{ Haplotype diversity } & \multirow[t]{2}{*}{ Number } \\
\hline & A & B & $\mathrm{C}$ & $\mathrm{D}$ & $\mathrm{E}$ & $\mathrm{F}$ & G & $\mathrm{H}$ & I & $\mathrm{J}$ & $\mathrm{K}$ & $\mathrm{L}$ & Number of haplotypes & Haplotype diversity ${ }^{\mathrm{a}}$ & \\
\hline Azores & 7 & 0 & 0 & 0 & 0 & 0 & 0 & 0 & 0 & 0 & 0 & 0 & 1 & 0.000 & 7 \\
\hline Spain & 0 & 2 & 1 & 1 & 1 & 0 & 0 & 0 & 0 & 0 & 0 & 0 & 4 & 0.900 & 5 \\
\hline Fair Isle & 0 & 1 & 0 & 0 & 0 & 2 & 3 & 0 & 0 & 0 & 0 & 0 & 3 & 0.767 & 6 \\
\hline Bristol & 0 & 0 & 0 & 0 & 0 & 0 & 3 & 1 & 1 & 0 & 0 & 0 & 3 & 0.700 & 5 \\
\hline Glasgow & 0 & 0 & 0 & 0 & 0 & 0 & 2 & 0 & 0 & 2 & 0 & 0 & 2 & 0.667 & 4 \\
\hline Norway & 0 & 3 & 0 & 0 & 0 & 0 & 0 & 0 & 1 & 0 & 1 & 1 & 4 & 0.800 & 6 \\
\hline Total & 7 & 6 & 1 & 1 & 1 & 2 & 8 & 1 & 2 & 2 & 1 & 1 & & & 33 \\
\hline
\end{tabular}

See Fig. 1 for relationships among the haplotypes

${ }^{\text {a }}$ Haplotype diversity (from equation 8.5 in Nei 1987) 
Table 2 Analysis of molecular variance results indicating percentage of variation among and within populations

D.f. Degrees of freedom

\begin{tabular}{lcclc}
\hline Source of variation & D.f. & Sum of squares & Variance components & Percentage of variation \\
\hline Among populations & 5 & 24.88 & $0.71 \mathrm{Va}$ & 39.53 \\
Within populations & 27 & 29.37 & $1.09 \mathrm{Vb}$ & 60.47 \\
& 32 & 54.24 & 1.80 & \\
Fixation index $F_{\text {st }}$ & 0.40 & & & \\
\hline
\end{tabular}

FJ896155). Three additional haplotypes were found among the three sequences downloaded from GenBank (Hap M, N, and $\mathrm{O}$ in Fig. 1). Haplotype diversity was high in all populations except for the Azores, where all individuals had identical sequences (Table 1). There was one shared haplotype between Spain, Fair Isle, and Norway (Hap B) and another between Fair Isle, Bristol, and Glasgow (Hap G; Table 1). There was also one shared haplotype between Bristol and Norway (Hap I). However, there were no shared haplotypes between the Azores and any of the other populations (Table 1). The haplotype network reconstructed using TCS suggested that haplotype B was ancestral. There was more variation within (60.5\%) than among (39.5\%) populations (Table 2). The Azores had high and significant genetic differentiation from all the other populations studied, as indicated by the higher $F_{\text {st }}$ values (all above 0.5; Table 3). In contrast, there was evidence for gene flow (as evidenced by negative and nonsignificant $F_{\text {sts }}$ ) among populations from Britain (Glasgow, Fair Isles, Bristol) and between Spain and Norway, which were significantly differentiated from the samples both from Britain and from the Azores.

The haplotypes of spotless starlings were not different enough from those of European starling to be used as an appropriate out-group. As can be seen in the haplotype network (Fig. 1), there is more genetic variability among the populations of European starling than between European and spotless starlings. A sample of rosecolored starling (Sturnus roseus) was sequenced to be used as a potential out-group, but in this case, the genetic divergence proved too high to be useful in the construction of phylogenies.

\section{Discussion}

The maximal ND2 divergence among the six populations studied was surprisingly low $(0.7 \%)$, especially considering that our sampling area extended from the mid-Atlantic to Scandinavia and included three supposed subspecies. In contrast, a study conducted on passerines in one single island (Hispaniola) found levels of ND2 maximum divergence of $1.2 \%$ (Townsend et al. 2007). Nevertheless, even with this low level of variation, our preliminary analysis shows that the Azorean birds are genetically distinct from all other populations studied. The Azorean population has only one variable site from the haplotype inferred to be ancestral (haplotype B) from the TCS analysis, adding some support to the hypothesis that the Azores population might indeed be a possible relic from the last glaciation. However, given the small sample size of our study, we must be very cautious accepting the inferred ancestral type, and additionally, we cannot exclude the possibility that haplotype B went undetected in the other populations studied. The lower degree of divergence of the Azorean population compared to other European populations might be due to the small size of the founder population and/or a bottleneck effect.

We found no genetic variation among the Azores individuals even though we had samples from two islands (Santa Maria and Terceira) that lie about $300 \mathrm{~km}$ from each other. The lack of haplotype diversity observed in the Azorean starling is in striking contrast with other studies on Atlantic birds. A recent study using the mtDNA cyt $b$ gene showed considerably higher haplotype diversity for the island canary (Serinus canaria); nine different haplotypes

Table 3 Pairwise genetic differentiation statistics $\left(F_{\mathrm{st}}\right)$ between the different populations studied based on haplotype frequency data
(1) Azores
(2) Spain
(3) Fair Isle
(4) Bristol
(5) Glasgow
(6) Norway

(1)

(2)

(3)

$0.45312^{*}$
$0.6853{ }^{*}$
$0.78216^{*}$
$0.84444^{*}$
$0.58230^{*}$

$0.26726^{*}$

(4)

(5)

(6)

$0.28427 *$

$-0.06900$

0.31579*

$-0.00405$

$-0.02637$

$0.28197^{*} \quad 0.35116^{*}$

$0.41158^{*}$

$F_{\text {st }}$ values significant after correction for multiple, nonindependent comparisons using Bonferroni correction are shown in bold $* P<0.05$ 
were found in only one of the Azorean islands (Dietzen et al. 2006). The lack of genetic variability found in the Azores starling population was not observed in any of the other populations studied, including in America where European starlings were introduced about 120 years ago (Cabe 1993).

The fact that we found common haplotypes between the Fair Isle populations and Spain, Bristol, Glasgow, and Norway populations is surprising if we remember that the Fair Isle birds are considered a distinct subspecies $(S$. vulgaris zetlandicus). The occurrence of Fair Isle haplotypes in the other populations studied, as well as the lack of differentiation from British populations based on $F_{\text {st }}$, indicates that the population is not as isolated as previously thought and might not deserve subspecies status. The spotless starling is sometimes treated as another subspecies of S. vulgaris (de la Cruz-Cardiel et al. 1997), and our study seems to support this hypothesis. Indeed, our study reveals that there were more genetic differences amongst $S$. vulgaris than between $S$. vulgaris and the two published Sturnus unicolor sequences that we used.

ND2 offers potential for resolving relationships among different subspecies of European starling. However, more work is needed to confidently identify the source population from which the Azores type might have originated or to which it is most closely related. Our study is not at all conclusive regarding the status of the Azorean starling as a subspecies but a more extensive sampling, and a study of nuclear genes or a wider range of genetic markers will help to clarify this issue.

Nevertheless, given the lack of genetic variability in the Azorean starling and the abundance of this species throughout the archipelago, especially in Santa Maria Island (Equipa Atlas 2008), starling control on a very local basis seems a reasonable measure to protect tern colonies. Several measures should be implemented simultaneously to reduce starling populations on the islets and increase tern's productivity, including discouragement of starlings roosting in the islet throughout the year (for example using scaring devices), destruction of starling nest contents in the islets, and if necessary, lethal control. These measures should be undertaken prior to arrival of terns to the breeding colonies, by mid-April at the latest, in order to avoid disturbance to the terns. The effectiveness of these starling control measures should be closely monitored and evaluated.

\footnotetext{
Acknowledgments Verónica Neves thanks the Portuguese Foundation for Science and Technology (FCT-MCTES) for funding (grant reference SFRH/BD/3436/2000). We are grateful to Sotirios Panagiatakopoulos and Juan Simón for help with the fieldwork, Jane Reid for providing the Fair Isle blood samples, Bernie Zonfrillo for providing the Glasgow samples, Emma Smith for providing the Bristol samples, Prof. Jan T Lifjeld from the Museum of Natural History of Oslo for providing the Norwegian samples, and Oriol Clarabuch and Jacob
}

González-Solís for providing those from Spain. Fieldwork in the Azores was undertaken with a permit from Direcção Regional do Ambiente.

\section{References}

Bannerman DA, Bannerman WM (1966) Birds of the Atlantic Islands 3: a history of the birds of the Azores. Oliver and Boyd, London

Cabe PR (1993) European starling (Sturnus vulgaris). In: Poole A, Gill F (eds) The birds of North America, no. 48. The academy of natural sciences, Philadelphia; The American Ornithologist's Union, Washington, DC

Clement M, Posada D, Crandall KA (2000) TCS: a computer program to estimate gene genealogies. Mol Ecol 9:1657-1660

de la Cruz-Cardiel PJ, Deceuninck B, Peris SJ, Elena-Rosselló JA (1997) Allozyme polymorphism and interspecific relationships in the common starling (Sturnus vulgaris) and spotless starling (S. unicolor) (Aves: Sturnidae). J Zool Syst Evol Res 35:75-79

Desjardins P, Morais R (1990) Sequence and gene organization of the chicken mitochondrial genome. A novel gene order in higher vertebrates. J Mol Biol 212:599-634

Dietzen C, Voigt C, Wink M, Gahr M, Leitner S (2006) Phylogeography of island canary (Serinus canaria) populations. J Ornithol $147: 485-494$

Equipa Atlas (2008) Atlas das Aves Nidificantes em Portugal (19992005) Instituto da Conservação da Natureza e da Biodiversidade, Sociedade Portuguesa para o Estudo das Aves, Parque Natural da Madeira e Secretaria Regional do Ambiente. Assírio \& Alvim, Lisboa

Excoffier L, Laval G, Schneider S (2006) ARLEQUIN version 3.01: an integrated software package for population genetics data analysis. University of Bern, Zoological Institute, Bern

Feare C (1984) The starling. Oxford University Press, New York

Ferrer X, Motis A, Peris SJ (1991) Changes in the breeding range of starlings in the Iberian Peninsula during the last 30 years: competition as a limiting factor. J Biogeogr 18:631-636

Fleischer RC, Mcintosh CE, Tarr CL (1998) Evolution on a volcanic conveyor belt: using phylogeographic reconstructions and $\mathrm{K}-\mathrm{Ar}$ based ages of the Hawaiian Islands to estimate molecular evolutionary rates. Mol Ecol 7:533-545

Frutuoso G (1561) Saudades da terra. Original manuscript from the XVI century, 2nd edn published in 6 volumes from 1978 to 1983. In: Rodrigues JBO (ed) Instituto Cultural de Ponta Delgada, Ponta Delgada

Fuchs J, Fjeldsa J, Bowie RC, Voelker G, Pasquet E (2006) The African warbler genus Hyliota as a lost lineage in the Oscine songbird tree: molecular support for an African origin of the Passerida. Mol Phylogenet Evol 39:186-197

Hartert E, Ogilvie-Grant W (1905) On the birds of the Azores. Novit Zool 12:80-128

Johnson KP, Clayton DH (2000) A molecular phylogeny of the dove genus Zenaida: mitochondrial and nuclear DNA sequences. The Condor 102:864-870

Lovette IJ, Rubenstein DR (2007) A comprehensive molecular phylogeny of the starlings (Aves: Sturnidae) and mockingbirds (Aves: Mimidae): congruent mtDNA and nuclear trees for a cosmopolitan avian radiation. Mol Phylogenet Evol 44:10311056

Maddison DR, Maddison WP (2000) MacClade version 4: analysis of phylogeny and character evolution. Sinauer Associates, Sunderland Massachusetts

Moore WS, DeFilippis VR (1997) The window of taxonomic resolution for phylogenies based on mitochondrial cytochrome 
b. In: Mindell DP (ed) Avian molecular evolution and systematics. Academic, New York, pp 83-118

Moritz C, Dowling TE, Brown WM (1987) Evolution of animal mitochondrial DNA: relevance for population biology and systematics. Ann Rev Ecol Syst 18:269-292

Nei M (1987) Molecular evolutionary genetics. Columbia University Press, New York

Neves VC (2005) Towards a conservation strategy of the roseate tern in the Azores. PhD thesis, University of Glasgow

Neves VC, Panagiotakopoulos S, Furness RW (2006) A control taste aversion experiment on predators of roseate tern (Sterna dougallii) eggs. Eur J Wildl Res 52:259-264

Posada D, Crandall KA, Templeton AR (2000) GeoDis: a program for the cladistic nested analysis of the geographical distribution of genetic haplotypes. Mol Ecol 9:487-488
Sorenson MD, Payne RB (2001) A single ancient origin of obligate brood parasitism in African finches: implications for host-parasite coevolution. Evol 55:2550-2567

Sorenson MD, Ast JC, Dimcheff DE, Yuri T, Mindell DP (1999) Primers for a PCR-based approach to mitochondrial genome sequencing in birds and other vertebrates. Mol Phylogenet Evol 12:105-114

Townsend AK, Rimmer CC, Lattas SC, Lovette IJ (2007) Ancient differentiation in the single-island avian radiation of endemic Hispaniolan chat-tanagers (Aves: Calyptophilus. Mol Ecol $16: 3634-3642$

Vaurie C (1959) The birds of the Palearctic fauna, Passeriformes. H. F. and G. Witherby, London

Zuccon D, Cibois A, Pasquet E, Ericson PG (2006) Nuclear and mitochondrial sequence data reveal the major lineages of starlings, mynas and related taxa. Mol Phylogenet Evol 41:333-344 